\title{
Organic livestock production: an emerging opportunity with new challenges for producers in tropical countries
}

\author{
M. Chander ${ }^{(1)}$, B. Subrahmanyeswari (2), R. Mukherjee ${ }^{(3)} \&$ S. Kumar (3) \\ (1) Principal Scientist, Indian Veterinary Research Institute, Izatnagar-243 122 (UP), India \\ (2) Associate Professor, NTR College of Veterinary Science, Gannavaram-521-102 (AP), India \\ (3) Senior Scientist, Indian Veterinary Research Institute, Izatnagar-243 122 (UP), India
}

Submitted for publication: 4 November 2009

Accepted for publication: 15 December 2010

\section{Summary}

Agrochemicals, veterinary drugs, antibiotics and improved feeds can increase the food supply while minimising production costs in various livestock production systems around the world. However, these days, quality-conscious consumers are increasingly seeking environmentally safe, chemical-residuefree healthy foods, along with product traceability and a high standard of animal welfare, which organic production methods are said to ensure. Organic production is not only a challenge for producers in developing countries, it offers new export opportunities as well.

Organic agriculture is practised by 1.8 million producers in 160 countries, and production of organically grown food continues to increase steadily by $15 \%$ per year. Most tropical countries are now exporting organic agricultural products but, apart from organic beef from Brazil and Argentina, organic livestock products are yet to take off. Most trade in organic livestock products is restricted to the European Union and other developed nations. Nevertheless, tropical countries cannot afford to neglect this emerging system of animal production. Organic production is knowledge- and management-intensive. Producers must be well versed in organic production standards, principles and practices, which require a high degree of knowledge and skill. In organic production, it is not simply the final product but the whole production process that must be inspected and approved by the accredited certification bodies. Organic livestock farming is still evolving, and further research is needed to make it sustainable. In this paper, the authors review the prospects of organic animal husbandry and its possible constraints in developing and tropical countries.

\section{Keywords}

Animal welfare - Certification standards - Consumer choices - Hot climates - Organic foods - Organic livestock production - Problems - Tropical environment.

\section{Introduction}

According to the Codex Alimentarius Commission, 'Organic agriculture is a holistic production management system which promotes and enhances agro-ecosystem health, including biodiversity, biological cycles, and soil biological activity. It emphasises the use of management practices in preference to the use of off-farm inputs, taking into account that regional conditions require locally adapted systems. This is accomplished by using, where possible, agronomic, biological, and mechanical methods, as opposed to using synthetic materials, to fulfill any specific function within the system' (9).

Organic animal husbandry, on the other hand, is defined as: a system of livestock production that promotes the use of organic and biodegradable inputs from the ecosystem in 
terms of animal nutrition, animal health, animal housing and breeding. It deliberately avoids the use of synthetic inputs such as drugs, feed additives and genetically engineered breeding inputs.

Farmers in resource-constrained countries traditionally use few external inputs, such as allopathic medicines and antibiotics, and follow grazing-based extensive or semiintensive production systems. In many ways, they are thus closer to organic farming systems, though largely by default. However, a lack of appropriate agro-ecological knowledge means that they fail to gain most of the environmental, social and economic benefits of organic management, which translate into ecological intensification (i.e. sustainable farming). Nevertheless, developing countries are becoming important suppliers of organic foods, since organic practices tend to suit the conditions under which their producers farm, especially in the case of smallholders living in rainfed areas. The fact that most organic markets and consumers are in developed countries and are prepared to pay a premium for organic products makes organic farming a niche area with excellent prospects for exports. Organic farming is practised in 160 countries and 37.2 million hectares of agricultural land are managed organically. Global sales of organic food and drink reached US\$54.9 billion in 2009 (35). Forty percent of the world's organic producers are in Asia, followed by Africa (28\%) and Latin America (16\%). The countries with the most producers are India $(677,257)$, Uganda $(187,893)$ and Mexico $(128,862)$. Yet animal products are still a small share of the organic market, compared to fruits, cereals and herbs, and, in terms of exports, are almost negligible in developing countries (35).

The evidence presented in a United Nations study, which explored the relationship between organic agriculture and food security in Africa, supports the argument that organic agriculture can be more conducive to food security in Africa than most conventional production systems, and is more likely to be sustainable in the long run (28). This is in line with the findings of the Food and Agriculture Organization of the United Nations (FAO) International Conference on Organic Agriculture and Food Security (13), where it was concluded that organic agriculture has many benefits, for developing countries in particular. Organic agriculture not only offers improved food security, but also an array of other economic, environmental, health and social advantages (28).

Under organic livestock production systems, consumers expect organic milk, meat, poultry, eggs, leather products, etc. to come from farms that have been inspected to verify that they meet rigorous standards, which mandate the use of organic feed, prohibit the use of prophylactic antibiotics (though in fact all antibiotics are discouraged except in medical emergencies) and give animals access to the outdoors, fresh air and sunlight. Production methods are based on criteria that meet all health regulations, work in harmony with the environment, build biological diversity and foster healthy soil and growing conditions. Animals are marketed as having been raised without the use of persistent toxic pesticides, antibiotics or parasiticides (33). Animal health and well-being through better living conditions, improved welfare measures and good feeding practices are ensured through a set of standards and the maintenance of written records by organic livestock farmers. Better management practices and prevention of illness are emphasised over treatment. Thus, the primary characteristics of organic livestock production systems are:

- well-defined standards and practices which can be verified

- greater attention to animal welfare

- no routine use of growth promoters, animal offal, prophylactic antibiotics or any other additives

- at least $80 \%$ of the animal feed grown according to organic standards, without the use of artificial fertilisers or pesticides on crops or grass.

To be precise, organic meat, milk and eggs are produced, harvested, preserved and processed according to verified organic standards. Practically speaking, organic methods call for a change in existing production systems.

Organic livestock farming is not a production method meant to solve all problems in livestock production. It is primarily a production method for a specific premium market, demanding high quality standards during the entire production process and advanced management qualifications. If organic livestock farming is to develop, the high expectations of consumers must not only be met but be seen to be met, to ensure their confidence in organic products (26).

\section{Organic crops versus livestock products}

Across the world, rapid advances have been seen in the production and trade of organic cereal, horticultural and even textile products. However, organic livestock and poultry systems are not nearly so developed. What few developments have taken place have been concentrated mostly in temperate climates. Although tropical countries are now producing and exporting organic agricultural products in ever-increasing quantities, only negligible developments have been reported in livestock production from these countries. This could be due to, among other things, limited export prospects for organic livestock products due to quality controls (so-called 'trade barriers') and self-sufficiency in importing countries. Nevertheless, 
some Latin American countries, such as Brazil and Argentina, not only produce organic beef but also export it to the European Union (EU) and the United States (USA). This development has been greatly facilitated by the sustained interventions and support of importing countries in the North (15).

Globally, efforts are being made to harmonise organic standards. These have met with considerable success, since most of the organic standards of the EU, the USA, the International Federation of Organic Agriculture Movements (IFOAM) and other regional and national standards show parity, especially those concerned with organic crop production. However, when it comes to livestock standards, there are significant variations in interpretations and requirements. For instance, the EU requirements on organic feed and fodder, antibiotics, etc. differ from those of the USA, laid down in the National Organic Program (NOP), although efforts are under way to achieve harmonisation in these standards and prospects look promising. Moreover, organic livestock production is more demanding than crop production since, to raise livestock organically, their fodder crops must also comply with strict organic standards. Organic livestock production is still evolving and has yet to overcome several barriers before it becomes popular with producers, especially farmers in tropical environments.

\section{Organic livestock standards}

Unlike traditional or conventional systems of production, organic production systems are governed by a set of standards that must be strictly followed by producers. Compliance with these standards is verified by certification agencies authorised by respective governments. A farm may be classified as organic if it meets the criteria stipulated in a set of guidelines known as 'organic standards'. The quality of production under organic management is ensured through certification procedures using internationally accepted standards. Organic certification guarantees not only the quality of the product but also the quality of the production process. In the case of conventional products, there is no way to guarantee production methods and procedures, but, in organic farming, production methods are certified to be safe and sound, as well as environmentally friendly. Plant and animal products intended for human consumption, and animal feed that is produced, processed and handled in accordance with these standards, are labelled 'organic products'. Organic agriculture is considered to be consumer- or market-driven, since such products are clearly identified through certification and labelling. Consumers take a conscious decision on how they wish their food to be produced, processed, handled and marketed. These standards, as well as the consumers themselves, thus have a strong influence over organic production.

Throughout the world, 468 organisations offer organic certification services. Most certification bodies are in Europe (37\%), followed by Asia (31\%) and North America (18\%). The countries with the most certification bodies are the USA, Japan, China and Germany. Forty percent of these certification bodies are approved by the EU; 32\% have International Organization for Standardization 65 (ISO65) accreditation and 28\% are accredited under NOP. Under India's National Programme on Organic Production (NPOP), which is named in the Foreign Trade and Development Regulation Act (FTDR) and legally applicable only to exports, 20 certification bodies have been authorised to oversee and verify the organic certification process. Similarly, East African nations, such as Tanzania and Kenya, have recently developed their own organic standards for crops and livestock, taking into account local production conditions as well as the requirements of international trade, especially when exporting to developed nations. An ever-increasing number of countries in the South are in the process of developing organic standards, and formulating rules and regulations to encourage organic food production, including animal products (35).

Organic farming can be practised by any farmer who is willing to follow its principles and guidelines to produce organic foods for his or her own household. However, if the food is to be marketed or traded, it must be certified by an accredited agency. The steps involved in certification are:

- registration of producers and the processing industries

- the provision of basic information on the crops and farm

- inspection and verification of the field and processing unit

- inspection of production methods and practices by the inspector appointed by the certifying agency.

A transition period of one to three years is required, during which no inorganic fertiliser or agrochemicals may be used on the farm and no antibiotics or synthetic hormones may be given to the animals, before produce from the farm can be marketed as organic. Since production during this transition period is generally low, farmers intending to become organic would suffer some losses, unless compensation was made for this. The cost of these products is further increased by the fact that organic production is generally $20 \%$ to $38 \%$ less than production using modern agricultural practices, at least in the initial years. Furthermore, the current standard of organic farming is quite stringent in terms of using organic manures, the type of animal feed/fodder required, the minerals or soil conditioners allowed, the quality of surface 
irrigation and underground water, and the agricultural practices employed on neighbouring farms. Producing organic food, therefore, requires considerable attention, care and skill and, above all, a strong connection to its market. In addition to the product quality standards that must be met, an equal emphasis is placed on the methods of production, which must also comply with stringent standards set for this purpose.

Finally, the 'organic' in organic agriculture is a labelling term that denotes products that have been produced in accordance with certain standards during food production, handling, processing and marketing, and confirms that these standards have been certified by a duly constituted certification body or authority. The organic label is, therefore, a process claim rather than a product claim. It should not necessarily be interpreted to mean that the foods produced are healthier, safer or entirely natural. It simply means that the products follow the defined standards of production and handling, although surveys indicate that consumers consider the organic label as an indication of purity and careful handling. The organic standard does not exempt producers and processors from compliance with the general requirements of statutory regulations, such as food safety regulations, pesticide registration, general food and nutrition labelling rules, etc. (12). The basic principles and standards for organic farming are formulated by IFOAM, an umbrella organisation that covers groups in more than 120 countries.

Unfortunately, standards are open to many interpretations and are not always easily enforceable. For example, the EU Regulations require that animals be given 'regular exercise' and that 'appropriate breeds' be used, yet there is no clear definition of either of these dictates. However, there are some clear high priorities for organic livestock.

Owing to organic prohibitions on certain veterinary drugs, health care protocols must be developed for each species, including research on alternative and complementary methods of disease prevention, effective non-chemical parasiticides, and preventive health care practices. Feeding strategies and specific foodstuffs must be developed to reduce the incidence of harmful pathogens and enhance breeding programmes for organic animals. Improvements in animal housing and husbandry and a better understanding of mixed crop and livestock systems are also important. Designing feeding strategies that provide adequate nutrition and high livestock productivity in areas with environmental constraints, such as arid and semi-arid areas, is key. Most of the current research on organic livestock is being undertaken in temperate areas. Though arid areas are largely dependent on livestock, little research is being conducted on organically raised livestock in these countries (14). Much greater research and developmental efforts are needed to promote organic livestock production and make it an economically rewarding proposition for farmers in tropical areas. This can be partially achieved by networking. The EU countries formed the Network for Animal Health and Welfare in Organic Agriculture (NAHWOA) to develop organic livestock production. This network was a collaborative research forum on animal health and welfare in organic livestock production, funded by the EU for the period between 1999 and 2001. The project brought together experts from 17 research institutes in 13 European countries. Likewise, equivalent networks can be formed in Asian, African and Latin American countries that have similar agro-climatic and socio-economic conditions (6).

\section{Animal welfare and organic animal husbandry}

Good animal health and welfare is an important goal for organic husbandry. In contrast to crops, animals are not just part of the farming system; they are also sentient creatures and as such deserve special care and moral consideration. Animal management is therefore different from crop management in that humans have a moral obligation to treat animals well and to intervene before they suffer or die, as this is unacceptable. Organic farming principles go further in promoting animal welfare than simply avoiding suffering; they also recommend unlimited access to 'natural' behaviour, which substantially broadens the concept of 'welfare'. Organic livestock production and animal welfare go hand in hand so, with the rising importance of animal welfare, organic animal production may also get a boost in coming years. There will thus be recognised benefits for developing countries that can evolve niche markets in higher welfare products, and the World Organisation for Animal Health (OIE) process for developing baseline standards for animal welfare will assist in the harmonisation and equivalency of standards in this area.

For instance, in Namibia, the development of animal welfare standards already plays an important role in market access. Namibia's quality assurance scheme, with its guaranteed traceability and animal welfare standards, has gained recognition for the Namibian beef industry of the quality of its products. This has resulted in increased market leverage and a trade advantage over its competitors. The beef market is also starting to cross over from the catering sector into the retail sector, adding another market for the product (1). Such examples may highlight the importance of animal welfare measures and the fact that welfare-oriented products can gain a market niche worth capitalising on. All of this indicates an excellent opportunity for producers in tropical countries. 
The animal welfare goal of avoiding suffering allows the use of synthetic medicines for treating sick animals, even when it results in that animal losing its organic status. This is the only circumstance in organic agriculture where the use of 'chemicals' is allowed and recommended, even in Europe (31). Nonetheless, no matter how diseases are managed, the most sustainable way of avoiding suffering and the need for veterinary treatment is to make more fundamental changes in husbandry methods, such as:

- breeding for increased disease resistance

- allowing more access to the natural environment

- introducing more species-appropriate housing

- feeding a well-balanced diet (31).

\section{Key considerations in organic livestock production}

Although changes in consumption patterns will continue to result in an average net increase in the demand for animal products, the major challenge in organic livestock production systems is to 'think the organic principles' into a wide range of diverse systems, under a wide range of circumstances and conditions, including systems which are not certified 'organic' at present. Developing and applying the principles of organic animal husbandry at all times requires a thorough analysis of the problems and opportunities involved and existing local knowledge (30). Some key considerations in organic animal husbandry that producers and other stakeholders need to take into account are listed below:

- the origins of livestock

- livestock feed

- living conditions

- waste management

- health care

- record keeping/the audit trail

\section{Origin of livestock}

All livestock (and all products from these livestock) that are sold, labelled or advertised as organic must be raised under continuous organic management from the last third of gestation or at hatching.

\section{Livestock feed}

The total rations of livestock that are produced under organic management must consist of agricultural products that have been organically produced and handled organically. This includes pasture, forage and crops. Certain non-synthetic and synthetic substances may be used as feed additives and supplements. Twenty percent of the feed for dairy cattle under nine months of age is allowed to come from non-organic sources. Plastic pellets, urea, manure and by-products from mammalian or poultry slaughter are not allowed.

\section{Living conditions}

An organic livestock producer must create and maintain living conditions that promote the health and accommodate the natural behaviour of the animal. These living conditions must include access to the outdoors, shade, shelter, fresh air, direct sunlight suitable for the particular species and access to pastures for ruminants.

\section{Waste management}

Organic livestock producers are mandated to manage manure so that it does not contribute to the contamination of crops, soil or water and optimises the recycling of nutrients.

\section{Health care}

Organic livestock production requires producers to establish preventive health care practices. These practices include:

- selecting the appropriate type and species of livestock

- providing adequate feed

- creating an appropriate environment that minimises stress, disease and parasites

- administering vaccines and veterinary biologics

- following animal husbandry practices to promote animal well-being in a manner that minimises pain and stress.

Producers cannot provide preventive antibiotics. Producers are encouraged to treat animals with appropriate protocols, including antibiotics and other conventional medicines when needed, but these treated animals cannot be sold or labelled as organic. Producers cannot administer hormones or other drugs for growth promotion.

\section{Record keeping/audit trail}

Organic livestock operations need to maintain records for a number of reasons. Certainly, records are important for the financial management of any organic livestock enterprise. However, records are also important to verify the organic status of the animals and the production, harvesting and handling practices associated with them 
and their products. These records must demonstrate compliance with the Organic Food Production Act in the USA and equivalent legislation elsewhere. Because organic production generally requires more record keeping than conventional crop production, it can seem onerous to producers in developing countries.

Almost all countries which are investing in their organic agricultural sector are taking note of the changing import environment in industrialised countries, and making the required changes to their production standards to enable them to export to the major consumer countries in the North. Developing countries in Asia, such as China, India, Thailand, Malaysia, Sri Lanka; in Africa, such as Kenya, Tanzania and Ethiopia; and among the South American countries, such as Argentina and Brazil, have already developed regulations, standards and certification procedures for organic livestock production. The number of such countries is increasing, mainly due to improved prospects for their exports, as well as a slowly growing domestic market for environmentally friendly food products (35).

\section{Challenges for researchers}

Organic livestock farming is still evolving and it will take some time to become sustainable on its own, using organic methods without depending on the artificial or chemical products used in conventional livestock production. This underscores the need for more research on organic alternatives, including medications, feeds and feeding practices that are compatible with organic management practices and standards. For instance, how can organic animal production be managed efficiently without some of the routine supplements, such as synthetic amino acids, considered essential in poultry and pig feeding? Alternatives must be developed so that neither production nor the animals suffer. The production factors cited as reasons to supplement with amino acids may be addressed by changes in animal and land management practices, novel feed sources and better feed handling. Methionine can be obtained from natural sources, since it is also found in naturally occurring proteins. Other options include improved pasture management and a balanced supplemental ration, composed of organic grains, legumes and oilseed meals. Temporarily confined poultry can be fed practical organic corn/soybean rations. Depending on how market conditions and organic standards evolve, novel organic products can be developed as supplements. Likewise, other alternatives must be researched and developed for organic livestock production.

One example highlights the importance of research and development into effective substitutes. On 18 September 2008, NOP of the United States Department of Agriculture
(USDA) announced that it had decided to implement a recommendation from the National Organic Standards Board (NOSB) to extend the use of synthetic sources of methionine in organic poultry production until 1 October 2010. The NOSB made this recommendation during its May 2008 meeting, after considering public comment from organic poultry producers. The producers explained that, in spite of research on multiple alternatives to synthetic methionine in poultry feed, they had not yet been able to identify practical alternatives from natural sources. Had NOP not granted this extension, the use of synthetic methionine would have been prohibited as of 1 October 2008. In allowing the extension, NOP explained that its goal was to provide the organic feed sector with enough time to create sufficient supplies of wholly natural substitute products (10). This case underlines the importance of speeding up research on acceptable organic alternatives to conventional products.

\section{Problems in developing organic animal husbandry}

While many tropical countries are making concerted efforts to boost organic production, especially of highvalue commercial crops, with considerable success, some serious problems are still restricting growth in organic farming. Some of these potential obstacles, especially when exporting livestock products, are as follows:

- lack of knowledge

- small farms

- problems in livestock feeding

- sanitary regulations

- traceability

- disease

- lack of training and certification facilities.

\section{Lack of knowledge}

In general, there is inadequate awareness about organic production practices, animal welfare issues and the requirements of importing countries, especially by individual organic trainers/advisers and farmers. Organic production calls for an in-depth understanding of the principles, standards, production practices and requirements of the organic certification agencies. Most of the literature on organic farming is available in English, through the print medium and the Internet. Much of this material is inaccessible to small-scale farmers in the South, where illiteracy is common and most do not speak English.

\section{Small farms}

In tropical countries, especially in Asia and Africa, smallscale farmers depend on livestock production for their livelihood. However, the landless animal husbandry 
system, which is common in India, is not allowed under organic systems of livestock production. Small farms are generally not suitable for the development of organic livestock production, especially for exports. Small farms mean small volumes, coupled with a lack of processing infrastructure, which results in poor quality. Milk production in tropical countries is largely the domain of small producers producing small volumes. Dilution, contamination and traceability are common problems with this small scale. Therefore, both technical and policy interventions are crucial to resolve these issues. Governments must support added-value initiatives and product marketing to help make the small farm production system more sustainable. Various essential goods and services, including credit, insurance and improved technologies, must be made available to improve the efficiency of small producers (27). Contract farming may be a potential solution. Under this system, many small farmers can contract their farms out to companies that produce organic food products on consolidated holdings. Such contract farming may be mutually beneficial and organic farming would be easier to pursue under such arrangements, for obvious reasons.

\section{Livestock feeding}

Livestock feeding has been a matter of much debate in the EU and particularly in the USA, where it has recently been resolved. The USDA has published new regulations addressing the use of pastures in organic livestock production. These rules strengthen the existing standards and clarify the USDA's emphasis on pasture-based livestock production for producers, consumers and certifiers.

An important requirement of the final regulation is that: 'animals must obtain a minimum of 30\% dry matter intake from grazing pasture during the grazing season'. This ruling establishes that not only must animals be outside, but that the pasture must be well managed, so that it makes a significant contribution to their nutrition (32). It has important implications for the livestock sector in tropical countries, where livestock intensification is increasingly being attempted to increase per-unit productivity. The organic alternative may help these farmers to reap greater benefits without intensifying their production systems, instead relying on the free-range, grazing-based systems that are already common in African and South and Central American countries.

Approximately two-thirds of organically managed land worldwide, roughly 23 million ha, was pasture in 2009. In developed countries, organic regulations are increasingly requiring that animals should be raised on pasture. In addition, further requirements are being placed on pasture quality. For example, EU regulations require that pastures be suitable for the natural nutritional and behavioural needs of particular species. These market drivers, along with a burgeoning market for grass-fed meat, has created great interest in developing pasture improvement strategies for the organic sector. Pastures may also have a large role in mitigating climate change through carbon sequestration. But, to date, little research has been done on organic pastures in arid regions, although these areas are largely dependent on their pastures and livestock (14).

\section{Sanitary regulations}

Only a few developing countries are able to export even conventional livestock products due to the strict sanitary requirements imposed by importing countries. These disease control regulations are even more strictly monitored when it comes to organic livestock products. Governments of tropical countries are taking the initiative in this regard by emphasising their adherence to the guidelines for clean milk production, good manufacturing practices (GMP), hazard analysis and critical control points (HACCP), International Organization for Standardization (ISO) certification, and best practices recommended by GLOBALGAP (a private sector body that sets voluntary standards for the certification of agricultural production processes), among others. These efforts must continue if access to international markets for organic livestock products is to be improved. This may be difficult but not impossible, especially since some developing countries, such as Argentina and Brazil, can already export organic livestock products to the EU (15). Massive efforts are needed to improve hygiene and disease control measures, especially during the production, processing and packaging stages. Many donor countries are coming forward to help developing countries to produce safe and nutritious products, including organic products, through project-based assistance. Such assistance must be harnessed effectively to develop organic livestock production systems. In addition, projects may be submitted that seek international help to develop goodquality organic animal products for consumers who are ready to pay a little more for such items.

\section{Traceability}

Importing countries emphasise farm-to-table traceability and, over recent times, this requirement has become even more important. It may be comparatively easy to trace the origin of products in western countries, where farms are large, with high volumes of production per farm. In the context of developing countries, where milk and meat are sourced from numerous small farmers, traceability is a more difficult option. Traceability tools that are both cost effective and suitable for mixed farming conditions in tropical countries, and, furthermore, that are acceptable to importing countries, will have to be developed. However, product traceability is also an issue in conventional production. Thus, whether developing nations seek to export organic products or conventional products, they will still need to evolve acceptable traceability mechanisms 
to assure consumers that their food comes from a reliable source, with high standards of food safety, hygiene and animal welfare.

\section{Existence of diseases}

The prevalence of infectious/zoonotic diseases also adversely affects trade in livestock products. Better animal health conditions are needed, especially in the case of organic livestock production. Foot and mouth disease (FMD), swine fever and Rift Valley fever restrict exports from much of the developing world. Thus, controlling such infectious diseases should be a high priority for these countries. Indian authorities, for example, are focusing on controlling FMD, an economically important OIE-listed disease which has far-reaching implications for production and trade. Such countries can begin with the creation of disease-free zones, in which organic livestock production can be encouraged. For the most part, the animal health services of tropical countries, which are largely under government control, are often criticised for their poor reach and efficiency.

In organic livestock production, the focus is on preventing health problems and diseases through better management practices. However, despite the benefits of such an approach for animal welfare and animal-friendly production, the basic standards seem, as yet, to be insufficient to ensure a higher animal health status and a better quality of product, when compared to conventional production. Comparative studies investigating the health situations of organic and conventional dairy farms show that there seems to be no fundamental difference between these two production methods in terms of the animal health status of dairy cows (26).

\section{Lack of training and certification facilities}

As yet, there are few local training and certification facilities available to small farmers at an affordable cost. Small farmers in tropical countries may find it difficult to pay for mandatory inspections which are often carried out by foreign certification agencies through their affiliates in producing countries. This may deter many farmers from switching over to organic production, especially if the domestic market is weak and export prospects are poor for livestock products. If we are to harness the potential benefits of organic farming, then training in organic production practices for both organic trainers/advisers and farmers is essential. Governments of tropical countries may consider sponsoring certification to encourage environmentally friendly production. In India, such efforts are being made but at present they occur mostly for highvalue commercial crops, for which a strong export market is already available.

In addition to these problems, organic livestock production is not yet developed in Asian countries due to a lack of organic feed and pastures. Limited amounts of certified organic animal products, mainly poultry and pork, are available in some domestic markets. Compliance requirements are so stringent that the first organic Japan Agricultural Standard- (JAS-) certified beef sold in Japan reportedly came from an Australian operation in 2008. Organic aquaculture (shrimp and fish), on the other hand, is emerging in China, Indonesia, Vietnam, Thailand, Malaysia and Myanmar (34).

\section{Threats to the development of organic animal husbandry}

Marketing opportunities may exist for developing countries to export organic meat and dairy products, especially in those countries where the climatic and ecological conditions favour the development of extensive production systems for livestock. However, meeting the certification requirements and quality standards of an external market can be extremely demanding. Moreover, there is no guarantee that the strong growth in demand seen in recent years will continue at the same level in the future. Therefore, careful research and analysis are strongly recommended to any country considering developing the production of organic meat and dairy products for external markets (12).

The prospect of a successful export industry is the major motivating factor in the development and growth of organic farming in most developing countries. These countries may have impressive livestock strength and other factors in their favour, yet the international trade in livestock from the developing world is a risky business, as far as organic livestock products are concerned $(12,15)$. An exporter must have an assured and certified supply chain to successfully enter international markets. For instance, the need to have a completely organic supply chain could present a problem for exporters of organic meat from these countries. Large-scale commercial farms usually undertake most organic livestock production for export; whereas, in developing countries, the livestock sector is dominated by small-scale producers, who have few resources and little ability to bear risk. Moreover, the EU may become self-sufficient in organic livestock products, leading to a reduced demand for imports and limiting the growth of the organic livestock sector in developing countries.

The EU is a net exporter of organic milk, milk products, pork, poultry and eggs. Some $85 \%$ of the world's meat trade and over $90 \%$ of the global milk trade takes place between developed countries (15). Developed nations place many restrictions on imports from developing countries, principally citing the poor disease control conditions, poor quality and traceability problems prevailing in these countries. Moreover, many developed 
countries, particularly in Europe, have huge food surpluses and farmer subsidy problems. Thus, only a handful of developing countries have export potential, including some in South America, southern Africa (Namibia, Botswana and Zimbabwe) and Southeast Asia. Tropical countries must make much more sustained efforts, even more so than in the case of conventional agricultural products, to make their presence felt in organic livestock production. One way could be to develop the organic livestock sector initially for domestic consumption, and gradually move towards organic livestock production for export.

Although many countries report a strong growth in demand for organic meat and dairy products, a number of instances can be cited where supply has exceeded demand. This has resulted in either a severe reduction in the price difference between organic and conventional products or organic products being sold as conventional products. This could call into question the achievability of some Western European countries' goals to increase the proportion of organic products in their domestic food consumption during this decade, as excess supply and an associated fall in price may well result in organic production becoming unprofitable. For example, before 2001, when export markets started to grow, Danish organic pork was in oversupply on the domestic market and prices were weak. Similarly, an estimated $20-30 \%$ of organic meat produced in Ireland is sold as conventional meat, while, in Switzerland, it is reported that a number of organically produced animals - especially pigs - are sold as conventionally reared animals. In the case of milk, in Austria, Denmark and the United Kingdom (UK), only one-third of organic milk is reportedly sold as such and the rest is sold as conventional milk. Consequently, some farmers' organisations in the EU have recently cautioned against the rapid conversion of farms to organic production, fearing that it could be out of step with the growth in demand (12). This experience in EU countries may be taken as a possible warning that tropical countries should be cautious when showing an interest in organic animal husbandry.

\section{Opportunities for tropical countries}

In spite of the potential drawbacks mentioned above, there are strong reasons for tropical countries to focus on organic livestock production. Some of these encouraging factors are:

- demand for organic livestock products is growing in the USA, the EU, Japan, Argentina and Brazil;

- Belgium, Luxembourg, the Netherlands and the UK import significant amounts of organic produce;

- the EU is a net importer of organic beef, sheep and goat meat;
- consumers pay a large price premium for organic food in Austria, Belgium, Germany and the UK;

- some developing countries are successfully exporting livestock products to developed countries;

- in 2001, 16\% of broiler meat and $40 \%$ of beef imported into the UK came from developing countries, such as Argentina and Brazil, that export organic livestock products to the EU (15);

- India and Nepal currently export certified organic honey, as do some African countries, sourced mostly from forests and small-scale producers. Organic honey is a good entry point to focus on, along with small ruminants, when developing organic livestock production in developing countries;

- to begin with, non-food livestock products, such as organic textiles and garments, including materials of animal origin such as hides, leather, and wool, offer hope for organic livestock production in tropical countries. The UK imports large amounts of raw textile materials and processed textiles; a significant proportion of these come from developing countries. Current global market trends show a rapid increase in international trade in organic textiles. Organic leather thus has the potential to become a valuable export commodity;

- indigenous technical knowledge, available in poorer and developing countries, may provide an effective substitute for veterinary care (16);

- the use of agrochemicals is almost nil in large parts of India and Nepal, and this is ideal for developing organic livestock production;

- native breeds of livestock, which predominate in tropical countries, are less susceptible to stress and disease, and so the need for allopathic medicines and antibiotics is much lower;

- the grass-based, extensive production systems and forest-based, animal production systems that are prevalent in many areas of these countries have considerable potential for conversion into organic animal husbandry;

- literacy is on the rise and the media are making consumers more aware of and concerned about animal welfare issues and healthy foods. This may well boost the domestic consumption of organic foods;

- a growing domestic market for organic products in developing countries may help boost the international organic market at the country and regional level.

Several Latin American, African and Asian countries have significant potential for organic milk and meat production, due to their compliance with legal requirements, low use of external inputs/resources, natural grazing and good agricultural practices. Among the African countries, 
Namibia has recently taken a step forward, in that its meat sector wants to take things further and obtain certification for organic meat production. Beef and mutton in Namibia generally come from free-range cattle and sheep and thus already have a good international reputation, prompting national agencies and donors to promote the organic production of beef and mutton. An agreement for a oneyear study to assess the potential of Namibia's organic meat production for markets in Finland and the rest of the EU was signed on 12 March 2010. It is anticipated that organic meat production and marketing could bring in additional income to the meat industry, which could include livestock producers as well. This study is expected to look at the best ways to improve market access for Namibian meat products in the EU, and particularly in Finland. Such mutually beneficial arrangements may evolve among other countries to promote market access for organic livestock products from developing countries into developed nations. It is expensive for intensive livestock producers to convert to organic production, but converting extensive, pasture-based systems could be much more attractive, economically speaking, if price premiums could be captured for organic meat and livestock products (20).

It has been reported, from countries like India, that local livestock production practices, especially in drylands and mountainous regions, are very close to organic production practices and, to a great extent, already comply with organic standards $(2,3,4,5,6,7,8,16,22,24,25)$. Such areas may be targeted to develop as hubs of organic animal husbandry, since this offers many advantages over intensive production. Such success stories from developing countries may help to pursuade other developing nations to switch over to organic livestock production. For instance, among Latin American countries, Argentina is in the forefront of organic production, and, alongside its vegetable and fruit market, there is a growing interest in animal products. Organic milk production there increased in 2003 and, although the size of the organic beef herd declined slightly in 2003, exports of organic beef increased from 50 tonnes to 270 tonnes, with the majority going to the UK (21). Argentina also has a strong domestic market for organic beef.

The FAO too recognises that, among developing countries, the largest and most advanced organic livestock sectors are observed in Argentina and Brazil. According to the Brazilian Beef Association, approximately 210,000 animals are being farmed organically in Brazil. If 2 ha of pasture per animal is required, that means at least 420,000 ha of pasture are under organic beef production (11). Brazilian companies are even buying processing plants in Argentina to expand their influence. Uruguay is also a significant producer of organic meat while Mexico and Nicaragua have initiated projects to produce organic meat, mainly for the domestic market.
One severe constraint on organic meat production in Latin America is the fact that their main consumers (in Europe and the USA) ask only for the best pieces (i.e. the sirloin, tenderloin and pistol cuts from the hindquarter). The rest of the meat must be sold on the domestic market, mostly as conventional meat (35). Developing countries in Asia and Africa may draw lessons from these experiences from Latin American countries in coming years.

Elsewhere, only limited data are available. However, it is evident that the interest in organic livestock products is on the rise, not only in response to the strong demand for organic products in national and export markets, but also because of the benefits it offers in maintaining soil fertility (12).

With Argentina's 20 years of experience in the organic market, coupled with a growth in its broiler industry in recent years, there is significant potential for Argentina to supply welfare-friendly organic broiler chickens to developed countries. Moreover, the development and implementation of standards for organic products in Thailand and Argentina over the past decade have also resulted in the growth of these countries' export markets in these products (1). Based on case studies carried out in Namibia, Argentina and Thailand, there is considerable potential for the export of animal-welfare-oriented products, including organic foods of animal origin, in all these countries. This development can be greatly assisted by the development of OIE baseline standards. Moreover, an increased emphasis on organic production in Argentina and Thailand should also bring benefits for animal welfare (1)

Many developing countries are forging ahead to ensure quality in their livestock products. For instance, the Government of the Republic of Korea recently revised its 'Environmentally Friendly Agriculture Promotion Act'. The National Assembly passed this Act in 1997 and quality certification of processed organic foods was implemented in 1998 (18). Mandatory certification of environmentally friendly agricultural products was initiated to harmonise with international standards (the Codex) and global organic standards in July 2001. According to the new regulation, any agricultural product claiming to be an 'environmentally friendly agricultural product', regardless of whether it is domestic or imported, or claiming to be 'organic' or with 'no agricultural chemicals' (antibiotic-free livestock products) or 'low agrichemical', must get approval from the Korean Government before promoting these claims at retail. In cases where labels claim 'organic' for imported livestock products, an authorised certification agent will visit the plant to determine if the product complies with Codex international guidelines (29). Such initiatives are likely to become more common in the future, to cope with a rising demand for eco-friendly, environmentally safe, healthy 
food products. For instance, in Argentina and Thailand, the promotion of organic production is being undertaken with government support to devise and promote recognised national organic standards. The organic food market is expected to continue to grow and, as long as they comply with the necessary standards, this offers excellent opportunities for exporters in developing countries to gain access to this market (1).

\section{Conclusion}

Livestock production has become far more sophisticated since the days of hunter-gatherers. Today, most production systems are intensive, with a very high per-animal productivity, due to better nutrition, health and housing management. However, the recent focus on and concerns over food quality, animal welfare, traceability, human health and environmental quality have led to the emergence of and growing interest in organic livestock farming, which is gradually spreading across the world. Tropical countries may find new opportunities in this premium market to export their own organic livestock products but it is a tough challenge, given the current sanitary conditions and prevalence of infectious diseases in these countries. Nevertheless, tropical countries have some natural advantages when it comes to organic livestock farming, which could be harnessed to boost organic livestock production for domestic consumption, initially, and exports in the long term. Nonetheless, this presents a formidable task, considering the stringent principles, guidelines, practices and standards of organic livestock production, as well as the mandatory certification procedures for such production systems. To benefit from this emerging system of food production, producers in developing countries must build their capacity and take into account their natural advantages.

\title{
Productions animales biologiques : nouvelles perspectives et nouveaux défis pour les éleveurs des pays tropicaux
}

\author{
M. Chander, B. Subrahmanyeswari, R. Mukherjee \& S. Kumar
}

\begin{abstract}
Résumé
Un grand nombre de systèmes de production animale dans le monde a recours aux produits agrochimiques, aux médicaments vétérinaires, aux antibiotiques et à la complémentation des aliments destinés aux animaux, ce qui leur permet d'accroître les quantités de denrées alimentaires produites tout en réduisant les coûts de production. Toutefois, à l'heure actuelle, les consommateurs sont devenus plus exigeants en matière de qualité et veulent que les denrées alimentaires qu'ils achètent soient exemptes de risque pour l'environnement et de résidus chimiques, tout en présentant des garanties de traçabilité et de respect des normes relatives au bien-être animal, ce que les méthodes de production biologique sont censées offrir. Pour les producteurs des pays en développement, la production biologique n'est pas seulement un défi ; elle constitue également une voie d'accès à de nouveaux débouchés d'exportation. L'agriculture biologique est pratiquée par 1,2 million de producteurs dans 141 pays, avec une production en hausse constante de $15 \%$ par an. Si la plupart des pays tropicaux exportent désormais des produits issus de l'agriculture biologique, les productions animales biologiques n'y ont guère connu un tel essor, à l'exception de la viande de bœuf " bio " produite au Brésil et en Argentine. Pour l'instant, I'Union européenne et d'autres pays développés constituent l'essentiel des destinations commerciales pour les productions animales biologiques. Néanmoins, les pays tropicaux ne peuvent se permettre de négliger ce nouveau système de production animale.
\end{abstract}


La production biologique requiert un haut niveau de savoir-faire et de gestion. Les éleveurs doivent être versés dans les normes, les principes et les pratiques de la production biologique, qui exigent des connaissances et des compétences spécialisées. Dans les productions biologiques, ce n'est pas seulement le produit final qui est visé par les procédures d'inspection et d'approbation des organismes de certification accrédités, mais la totalité du processus de production. La production animale biologique est en pleine évolution, et il faudra mener des recherches approfondies pour en assurer la pérennité. Les auteurs examinent les perspectives d'avenir des productions animales biologiques, ainsi que les difficultés spécifiques des pays en développement et tropicaux dans ce domaine.

\title{
Mots-clés
}

Bien-être animal - Climats chauds - Denrées alimentaires issues de l'agriculture biologique - Environnement tropical - Normes de certification - Préférences des consommateurs - Problème - Production animale biologique.

\section{Producción ganadera ecológica: nuevas posibilidades y dificultades para los productores de países tropicales}

\author{
M. Chander, B. Subrahmanyeswari, R. Mukherjee \& S. Kumar
}

\section{Resumen}

En diversos sistemas de producción ganadera de todo el mundo se recurre a productos agroquímicos, medicamentos veterinarios, antibióticos y alimentos enriquecidos para obtener una mayor cantidad de alimentos reduciendo al mínimo posible los costos de producción. Hoy en día, sin embargo, los consumidores se muestran exigentes en materia de calidad y prefieren cada vez más consumir alimentos saludables, exentos de residuos químicos y obtenidos de forma respetuosa con el medio ambiente, con garantías de rastreabilidad y atendiendo a estrictas normas de bienestar animal, parámetros que presumiblemente cumplen los métodos de producción ecológica. Para los productores de los países en desarrollo, este tipo de producción no sólo presenta dificultades, sino que también abre nuevas posibilidades de exportación.

Actualmente hay 1,2 millones de productores de 141 países que practican la agricultura ecológica, y la producción de alimentos obtenidos con métodos ecológicos sigue progresando a un ritmo constante del $15 \%$ anual. Aunque la mayoría de los países tropicales exportan ahora productos agrícolas ecológicos, la producción animal ecológica todavía no ha despegado, con la salvedad de la carne vacuna ecológica de Brasil y Argentina. Por ahora, el mercado de los productos ganaderos ecológicos se circunscribe casi exclusivamente a la Unión Europea y otros países desarrollados. Sin embargo, los países tropicales no pueden permitirse el lujo de pasar por alto este nuevo sistema de producción animal.

La producción ecológica es un proceso exigente, que requiere profundos conocimientos y mucha gestión. Los productores deben estar versados en las normas, principios y prácticas de la producción ecológica, y ello exige 
competencias y conocimientos especializados. En la producción ecológica, los organismos acreditados de certificación no controlan y aprueban únicamente el producto final, sino el proceso productivo en su conjunto. La producción ganadera ecológica está en plena evolución, y hace falta más investigación para lograr que sea duradera a largo plazo. Los autores examinan las perspectivas de estos métodos de producción animal, así como los posibles impedimentos que pueda haber en este ámbito en los países en desarrollo y tropicales.

\section{Palabras clave}

Alimentos ecológicos - Bienestar animal - Climas cálidos - Medio tropical - Normas de certificación - Preferencias del consumidor - Problemas - Producción ganadera ecológica.

\section{References}

1. Bowles D., Paskin R., Gutiérrez M. \& Kasterine A. (2005). Animal welfare and developing countries: opportunities for trade in high-welfare products from developing countries. In Animal welfare: global issues, trends and challenges (A.C.D. Bayvel, S.A. Rahman \& A. Gavinelli, eds). Rev. sci. tech. Off. int. Epiz., 24 (2), 783-790.

2. Chander M. (2003). - Indian national standards for organic animal husbandry: a stakeholders' consultation. Organic Standard, 34, 6-8.

3. Chander M. \& Mukherjee R. (2005). - Organic animal husbandry: concept, status and possibilities in India - a review. Indian J. anim. Sci., 75 (12), 1460-1469.

4. Chander M. \& Subrahmanyeswari B. (2007). - Setting up an organic dairy farm: steps. Indian Dairyman, 59 (2), 59-63.

5. Chander M. \& Subrahmanyeswari B. (2010). - Indigenous breeds can improve sustainability of organic livestock production systems: an Indian perspective. Ecol. E Farming, $47,16-20$

6. Chander M. \& Wanapat M. (2006). - Networking for organic livestock production development in Asian countries: a suggested paradigm. In Proc. 1st International Federation of Organic Agriculture Movements (IFOAM) International Conference on Animals in Organic Production, 23-25 August, University of Minnesota, St Paul. IFOAM, 80-87.
7. Chander M., Kumar S., Mukherjee R. \& Subrahmanyeswari B. (2008). - Switching to organic livestock production: constraints and opportunities for India. In Global organic agribusiness: India arrives! (M.K. Manoj, Y.S. Paul \& N. Muralidhara, eds), papers presented at India Organic 2008, 27-29 November, New Delhi. Westville Publishing, New Delhi, 43-49.

8. Chander M., Kumar S., Rathore R.S., Mukherjee R., Kondaiah N. \& Pandey H.N. (2007). - Organic vis-à-vis conventional livestock production potential in India. In Proc. International Conference on Organic Agriculture and Food Security, 3-5 May, Rome. Food and Agriculture Organization of the United Nations, Rome, 48-49.

9. Codex Alimentarius (2007). - Organically produced foods, 3rd Ed. Codex Alimentarius Commission, World Health Organization (WHO)/Food and Agriculture Organization of the United Nations (FAO), Rome, 51 pp.

10. Coody L. (2008). - NOP extends use of synthetic methionine. Organic Standard, 91, 18.

11. Euclides Filho K. (2004). - Supply chain approach to sustainable beef production from a Brazilian perspective. Special issue: trends and development in organic livestock farming systems: papers presented at a session of the 9th World Conference of Animal Production congress in Porto Alegre, 26-31 October 2003, Brazil. Livest. Prod. Sci., 90 (1), 53-61. 
12. Food and Agriculture Organization of the United Nations (FAO) (2002). - Market developments for organic meat and dairy products: implications for developing countries. Committee on Commodity Problems, Intergovernmental Group on Meat and Dairy Products, 19th session, 27-29 August, Rome, 28 pp.

13. Food and Agriculture Organization of the United Nations (FAO) (2007). - Proc. International Conference on Organic Agriculture and Food Security, 3-5 May, Rome. FAO, Rome, $142 \mathrm{pp}$.

14. Food and Agriculture Organization of the United Nations (FAO) (2009). - Organic Research Centres Alliance project proposal: start-up phase for the Organic Research Centres Alliance (ORCA) and prototype centre on humid and subhumid areas (HUSHA). GCP/GLO/289/MUL. FAO, Rome. Available at: www.fao.org/fileadmin/templates/organicag/ files/HUSHA_Proposal_for_website.pdf (accessed on 29 September 2011).

15. Harris P.J.C., Browne A.W., Barrett H.R. \& Gandiya F. (2003). - The organic livestock trade from developing countries: poverty, policy and market issues. In Final technical report, Programme of Advisory Support Services for Rural Livelihoods, Department for International Development. School of Science and the Environment, Coventry University, United Kingdom.

16. Kumar S., Rathore R.S., Mukherjee R., Das G. \& Chander M. (eds) (2006). - Organic animal husbandry: concepts, standards and practices. Indian Veterinary Research Institute, Izatnagar, 166 pp.

17. Mukherjee R. \& Chander M. (2005). - Validating indigenous technical knowledge (ITK) for animal health management under organic production systems: mastitis in dairy cattle. In Integrating livestock-crop systems to meet the challenges of globalization. Proc. Animal Husbandry Association of Thailand (AHAT)/British Society of Animal Science (BSAS) International Conference, 14-18 November, Khon Kaen, Thailand, Vol. II (P. Rowlinson, C. Wachirapokorn, P. Pakdee \& M. Wanapat, eds). BSAS, T61-62.

18. National Agricultural Products Quality Management Service (NAQS) (2004). - Management of organic agricultural products. Available at: www.naqs.go.kr/english/business/ business_6.jsp (accessed in 2010).

19. Sasman C. (2010). - Study to assess organic meat markets. New Era, 15 March 2010. Available at: www.newera. com.na/article.php?title=Study_to_assess_organic_meat_mar kets\&articleid=32128 (accessed on 15 October 2011).

20. Scialabba N.E. \& Hattam C. (eds) (2002). - Organic agriculture, environment and food security. Environment and Natural Resources Management Series No. 4. Food and Agriculture Organization of the United Nations, Rome, 258 pp. Available at: www.fao.org/docrep/005/y4137e/ y4137e00.htm (accessed on 11 October 2011).

21. Servicio Nacional de Sanidad y Calidad Agroalimentaria (SENASA) (2003). - Situation of organic production in Argentina in 2003. SENASA, Buenos Aires.
22. Subrahmanyeswari B. (2007). - Knowledge attitude and practices of organic farmers with special reference to livestock farming: an exploratory study in Uttarakhand State of India. Ph.D. thesis submitted to the Indian Veterinary Research Institute (Deemed University), Izatnagar

23. Subrahmanyeswari B. \& Chander M. (2006). Demonstration units as a strategic research and extension plan to diffuse organic livestock farming in India. In Proc. 1st International Federation of Organic Agriculture Movements (IFOAM) International Conference on Animals in Organic Production, 23-25 August, University of Minnesota, St Paul. IFOAM, 282-286.

24. Subrahmanyeswari B. \& Chander M. (2008). - Compatibility of animal husbandry practices of registered organic farmers with organic animal husbandry standards (OAHS): an assessment in Uttarakhand. Indian J. anim. Sci., 78 (3), $322-327$

25. Subrahmanyneswari B. \& Chander M. (2008). - Livestock production practices of registered organic farmers in Uttarakhand State of India. In Proc. 2nd Scientific Conference of the International Society of Organic Agriculture Research (ISOFAR) in conjunction with the 16th International Federation of Organic Agriculture Movements (IFOAM) Organic World Congress, 18-20 June, Modena, Italy, 64-67.

26. Sundrum A. (2001). - Organic livestock farming: a critical review. Livest. Prod. Sci., 67, 207-215.

27. Taneja V.K. (2005). - Integrating livestock-crop systems to meet the challenges of globalization: animal genetic resources in changing production systems in Asia. In Integrating livestock-crop systems to meet the challenges of globalization. Proc. Animal Husbandry Association of Thailand (AHAT)/British Society of Animal Science (BSAS) International Conference, 14-18 November, Khon Kaen, Thailand, Vol. I (P. Rowlinson, C. Wachirapokorn, P. Pakdee \& M. Wanapat, eds). BSAS, 317-324.

28. United Nations Conference on Trade and Development (UNCTAD) (2008). - Organic agriculture and food security in Africa. United Nations Environment Programme (UNEP)UNCTAD Capacity-building Task Force on Trade, Environment and Development. UN, New York and Geneva, $47 \mathrm{pp}$.

29. United Nations Economic and Social Commission for Asia and the Pacific (ESCAP) (2002). - National study: Republic of Korea. In Organic agriculture and rural poverty alleviation: potential and best practices in Asia. ESCAP, Bangkok, Thailand. Available at: www.unescap.org/rural/doc/OA/OABgrd.htm (accessed on 10 October 2011).

30. Vaarst M., Roderick S., Byarugaba D.K., Kobayashi S., Rubaire-Akiiki C. \& Karreman H.J. (2006). - Sustainable veterinary medical practices in organic farming: a global perspective. In Global development of organic agriculture (N. Halberg, H.F. Alrøe, M.T. Knudsen \& E.S. Kristensen, eds). CABI, Wallingford, United Kingdom, 241-276. 
31. Van der Honing Y. (ed.) (2005). - Book of abstracts of the 56th Annual Meeting of the European Association for Animal Production, 5-8 June, Uppsala, Sweden. EAAP book of abstracts, Vol. 11. Wageningen Academic Publishers, Wageningen, 409 pp.

32. Villalón A.N. (2010). - At last! USDA issues final rule on pasturing livestock. Organic Standard, 107, 16.

33. Von Borell E. \& Sørensen J.T. (2004). - Organic livestock production in Europe: aims, rules and trends with special emphasis on animal health and welfare. Livest. Prod. Sci., 90 (1), 3-9.

34. Wai Ong Kung (2009). - Organic Asia: from back to nature movement and fringe export to domestic market trend. In The world of organic agriculture: statistics and emerging trends 2009 (H. Willer \& L. Kilcher, eds). International Federation of Organic Agriculture Movements, Bonn; Research Institute of Organic Agriculture, Frick, Switzerland; International Trade Centre, Geneva. Available at: www.organicworld.net/yearbook-2009.html (accessed on 2 March 2009).
35. Willer H. \& Kilcher L. (eds) (2011). - The world of organic agriculture: statistics and emerging trends 2011. International Federation of Organic Agriculture Movements, Bonn \& Research Institute of Organic Agriculture, Frick, Switzerland. Available at: www.organic-world.net/ yearbook-2011contents.html (accessed on 15 October 2011). 
